\title{
KETERAMPILAN LITERASI UNTUK MENINGKATKAN BUDAYA SUKA BACA DI SEKOLAH AMALIA
}

\author{
Rosmaini $^{*}$, Arnita ${ }^{1}$, Fahrur Rozi ${ }^{2}$ \\ ${ }^{1}$ Jurusan Bahasa dan Sastra Indonesia, Fakultas Bahasa dan Seni, Universitas Negeri Medan, \\ Medan, Indonesia \\ ${ }^{2}$ Jurusan PGSD, Fakultas Ilmu Pendidikan, Universitas Negeri Medan, Medan, Indonesia \\ * Penulis Korespodensi: rosmainifadil@yahoo.com
}

\begin{abstract}
Abstrak
Hampir 70\% siswa kelas satu dan dua di sekolah Amalia kemampuan membacanya rendah. Dan lebih dari 50\% siswa kelas tiga keterampilan membaca khusunya membaca pemahaman juga masih rendah. Tak jauh berbeda dengan keterampilan membaca, lebih dari $70 \%$ siswa kelas tiga memiliki kemampuan mengarang rendah. Begitu juga dengan TK Amalia lebih dari 50\% siswanya belum memiliki kemampuan dan keterampilan membaca yang baik, dan kesadaran fonologis yang masih rendah. Peran serta guru dalam mengikuti pelathan-pelatihan yang bertujuan meningkatkan sumber daya juga masih rendah. Sekolah jarang diundang untuk mengikuti pelatihan-pelatihan yang diadakan oleh dinas setempat.Oleh karena itu perlu dilakukan kegiatan-kegiatan yang dapat meningkatkan pemahaman dan keterampilan guru dalam melakukan inovasi pembelajaran khusunya keterampilan literasi. Dengan kegiatan tersebut, dapat menumbuhkan minat membaca dan budaya suka baca pada siswa SD dan TK di Sekolah Amalia.
\end{abstract}

Kata kunci : keterampilan literasi, mini book, minat membaca

\begin{abstract}
Almost 70\% of first and second graders at Amalia's school have a low reading ability. And more than $50 \%$ of students of grade 3 reading skills especially reading comprehension are still low. Not much different from reading skills, more than $70 \%$ of third graders have low writing skills. Likewise with Amalia kindergarten more than $50 \%$ of students do not have the ability and good reading skills, and phonological awareness is still low. Participation of teachers in follow-training training aimed at improving resources is also low. Schools are rarely invited to attend trainings organized by local agencies. Therefore it is necessary to do activities that can improve the understanding and skills of teachers in conducting learning innovations especially literacy skills. With these activities, can foster interest in reading and reading culture in elementary and kindergarten students at Amalia School.
\end{abstract}

Keywords: literacy skills, mini book, reading interest

\section{PENDAHULUAN}

Literasi atau kemampuan baca-tulis, merupakan kemampuan yang penting dalam proses perkembangan anak sekolah, karenanya kemampuan tersebut menjadi salah satu indikator perkembangan kemampuan anak menuju peningkatan prestasi di sekolah. Stimulasi pencapaian kemampuan literasi mulai dari awal sejak usia prasekolah penting dilakukan.

Menurut Schickedanz (2013) pentingnya mendeteksi awal kemampuan literasi anak akan memberikan informasi terkait kesulitan membaca dan menulis. Hal senada dari penelitian Reese at.al (2000) ditemukan bahwa pengalaman anak berinteraksi dengan literasi sejak dini akan menyiapkan anak secara matang untuk mengikuti pembelajaran di sekolah formal. Lebih lanjut dalam penelitian
(Hilbert \& Eis, 2014) mengemukakan penggunnaan/penerapan intervensi awal perkembangan literasi awal terhadap kemampuan literasi anak terutama berkaitan dengan kemampuan penamaan gambar, bersajak/aliterasi dan kosa kata pada keluarga yang bepenghasilan rendah mempunyai manfaat yang sangat besar bagi kehidupan anak selanjutnya. Intervensi awal yang dilakukan oleh guru maupun orang tua sebenarnya, membantu anak dalam mengembangkan kemampuan literasi dan bahkan sebagai media untuk mendiagnosa kesulitan anak terkait kemampuan literasinya.

Secara umum, hasil pendidikan kita belum memuaskan. Hal itu tercermin pada laporan beberapa lembaga internasional berkenaan dengan tingkat daya saing sumber daya manusia kita dengan negaranegara lain. Menurut Ronald Hutasuhut dalam 
Kompasiana.com Tanggal 22 Maret 2017, peringkat HDI (Human Develompment Index) atau kualitas Sumber Daya Manusia Indonesia (SDM) Indonesia terus menurun, tahun 2000 berada di peringkat 109 dari 174 Negara, peringkat 110 dari 174 Negara di tahun 2014 dan peringkat 113 dari 174 Negara di tahun 2015. Di bawah Indonesia saat ini ada Palestina yang menempati peringkat ke-114.

$\begin{array}{lccr}\text { Menurut } & \text { Ketua Forum Pengembangan } & \text { Budaya } \\ \text { Literasi } & \text { Indonesia Satria Darma dalam }\end{array}$ Republika.co.id, 15 Mei 2017, berdasarkan survei banyak lembaga internasional, budaya literasi masyarakat Indonesia masih sangat rendah. Begitu juga hasil Programme for International Student Assessment (PISA) menyebutkan budaya literasi masyarakat Indonesia pada 2012 terburuk kedua dari 65 negara yang diteliti di dunia. Indonesia menempati urutan ke 64 dari 65 negara tersebut. Sementara Vietnam justru menempati urutan ke-20 besar.

Salah satu hal penting yang memegang peranan dalam keberhasilan siswa dalam berliterasi adalah guru. Strategi yang harus dikelola dan diterapkan oleh guru saat pengajaran membaca maupun menulis di kelas harus lebih variatif, sehingga siswa tidak jenuh mengikuti pembelajaran. Strategi ini menunjukkan peran penting dari seorang guru untuk mencapai tujuan pembelajaran. Secara umum, ada dua tanggung jawab yang mendasar dari seorang guru dalam mengajar bahasa di kelas yaitu untuk menyediakan lingkungan belajar bahasa yang kaya dan mendukung siswa dalam penggunaan bahasa.

Selama ini dalam pembelajaran, strategi guru dalam mengajarkan membaca dan menulis masih konvensional. Padahal, Banyak strategi membaca dan menulis yang bisa digunakan guru dalam pembelajaran di kelas awal dan permulaan, seperti strategi membacakan cerita dengan teknik read aloud, guru meningkatkan kesadaan fonologis pada anak agar dapat membaca dengan baik, dan melakukan penilaian membaca untuk memantau kemajuan belajar membaca pada anak. Sedangkan untuk meningkatkan keterampilan menulis, maka guru dapat mengembangkan komponen ketrerampilan transkrip dan mengembangkan ide.

Mitra yang akan dilibatkan dalam kegiatan ini adalah SD dan TK Amalia. Kedua sekolah tersebut berada dalam satu yayasan yang sama, dan terletak di Kecamatan Medan Denai kota Medan. Jarak lokasi kedua mitra dari Universitas Negeri Medan lebih kurang 7,9 km. Berdasarkan informasi yang didapat dari kepala sekolah SD Amalia, hampir 70\% siswa kelas satu dan dua di sekolah tersebut kemampuan membacanya rendah. Dan lebih dari 50\% siswa kelas tiga keterampilan membaca khusunya membaca pemahaman juga masih rendah. Tak jauh berbeda dengan menulis, lebih dari $70 \%$ siswa kelas tiga memiliki kemampuan mengarang rendah.
Berdasarkan wawancara pada kepala sekolah, guruguru mereka belum pernah terlibat dalam kegiatankegiatan inovasi pembelajaran yang diadakan pemerintah maupun lembaga-lembaga tertentu. Pembelajaran membaca dan menulis masih menggunakan metode pembelajaran yang konvensional.

Sebenarnya dalam pembelajaran perlu dilakukan inovasi untuk meningkatkan minat anak dalam berliterasi, sehingga dapat menumbuhkan sikap positif anak dalam belajar khususnya membaca. Perlu juga dilakukan kegiatan-kegiatan yang dapat meningkatkan pemahaman dan keterampilan guru dalam melakukan inovasi pembelajaran. Sebagai bagian dari perguruan tinggi yang menghasilkan guru, maka perlu untuk lebih pro aktif melakukan kegiatan yang memberi manfaat positif bagi guru. Oleh karena itu perlu dilakukan program atau kegiatan keterampilan literasi bagi guru-guru untuk menumbuhkan minat membaca dan budaya suka baca pada siswa SD dan TK di Sekolah Amalia.

\section{METODE PELAKSANAAN}

Strategi keterampilan literasi adalah strategi yang dilakukan dengan tiga tahapan membaca, yaitu:

1. Kesadaran fonologis

Bentuk kegiatannya adalah : diskusi tentang mengenalkan bunyi bahasa dan menyusun rancangan kegiatannya, diskusi tentang mengenalkan suku kata dan menyusun rancangan kegiatannya. diskusi tentang mengenalkan kata dan menyusun rancangan kegiatannya.

2. Membaca Cerita (read aloud)

Strategi-strategi kunci untuk membaca nyaring ialah:Pengantar/Pendahuluan, membaca buku, jaga aliran bacaan dan bangun pemahaman. umpan balik

3. Mengukur kecepatan membaca (running record) Bermanfaat untuk dokumen tentang perjalanan membaca siswa, membuat program membacas esuai kebutuhan siswa, menyediakan buku sesuai dengan kebutuhan siswa

4. Keterampilan menulis dan membuat media membaca dan menulis mini book

Menentukan cerita yang akan dibuat, mulai membuat draft cerita, menulis cerita di mini book berdasarkan draft yang sudah dibuat. Satu halaman dapat terdiri dari satu kata atau satu kalimat sederhana.

5. Rencana tindak lanjut

Peserta diminta untuk membuat program peningkatan klualiatas membaca dan menulis. Tujuannya agar terciptanya keterampilan literasi di kalangan siswa di sekolah Amalia.

\section{HASIL DAN PEMBAHASAN}

\subsection{Kegiatan Pendahuluan}

Kegiatan pendahuluan diawali dengan acara ceremonial, pembukaan, menyanyikan lagu nasional, kata sambutan dari panitia dan pihak sekolah dan ditutup dengan doa. Panitia telah menyiapkan 
peralatan dan bahan pelatihan. Selanjutnya kegiatan diambil alih oleh fasilitator, setiap peserta yang terdiri dari guru TK dan Guru SD Amalia yang berjumlah 25 orang dibagi menjadi 5 kelompok kecil. Setiap kelompok menentukan nama kelompoknya berdasarkan nama-nama yang berhubungan dengan kemampuan literasi di kelas awal. Tempat duduk peserta dibuat dengan cara berkelompok, masingmasing kelompok terdiri dari guru laki-laki dan perempuan.

Sebelum materi pelatihan diberikan, fasilitator menyampaikan kontrak pelatihan yang harus disepakati bersama antara fasilitator dan peserta. Setiap item kontrak pelatihan diucapkan bersamasama dan dijelaskan sehingga diharpkan pelatihan berjalan dengan baik dan lancar.



Gambar 5.1. Fasilitator menyampaikan kontrak kuliah

Fasilitator juga menyampaikan materi-materi pelatihan yang akan disampaikan diantaranya:

1. Unit 1 : Kesadaran Fonologis

2. Unit 2 : Membacakan Cerita (Read Aloud)

3. Unit 3 : Penilaian Membaca

4. Unit 4 : Ketrampilan Menulis

5. Unit 5 : Rencana Tindak Lanjut

\section{Kesadaran Fonologis}

Tahap awal kegiatan ini, peserta dibekali tentang latar belakang, tujuan dan manfaat kesadaran fonologis. Peserta diminta untuk mengemukakan gagasan dan pendapatnya mengenai kesadaran fonologis, kegiatan dan bahan serta alat yang mendukung untuk memahami tentang kesadaran fonologis. Peserta menulis di kertas HVS dan saling berdiskusi dalam kelompok dan juga melalui presentasi di depan kelas. Kemampuan membedakan bunyi-bunyi dalam bahasa lisan, Kemampuan membedakan suku kata dalam kata yang dilisankan, Kemampuan membedakan kata-kata yang membentuk kalimat lisan disebut dengan kesadaran fonologis. Kegiatan yang mendukung untuk memahami kesadaran fonologis antara lain, mengenal bunyi huruf, mengenal suku kata dan mengenal kata. Sedangkan media atau bahan yang digunakan seperti kartu huruf, kartu kata, nama peserta, nama-nama benda di kelas, buku pelajaran siswa dan Big Book.
Pada kegiatan inti, peserta dibimbing untuk memahami cara mengenalkan bunyi bahasa, suku kata, dan mengenal kata dalam kalimat. Mengajarkan anak-anak untuk memanipulasi bunyi-bunyi dalam suatu bahasa membantu mereka untuk belajar membaca. Hal ini membantu mereka untuk mendecode kata-kata dan untuk mengingat kata-kata yang familiar/dikenal. Hal ini juga mendorong pemahaman bacaan, tidak diragukan lagi karena hal ini membantu anak-anak membaca dan mengenali kata-kata secara efektif. Agar anak-anak memahami apa yang mereka baca, mereka harus mampu membaca kata-kata dengan cepat dan secara akurat. Membaca cepat dan akurat membebaskan anak-anak agar memusatkan perhatian mereka pada makna dari apa yang mereka baca.Pengajaran kesadaran fonemik membantu anak-anak belajar mengeja. Mengajar kesadaran fonemik, khususnya bagaimana mensegmen/memecah kata-kata menjadi fonem, membantu anak-anak belajar mengeja. Penjelasan untuk hal ini ialah mungkin anak-anak yang memiliki kesadaran fonemik memahami bahwa bunyi-bunyi dan huruf-huruf saling terkait dengan cara yang dapat diprediksi. Dengan demikian, mereka dapat menghubungkan bunyi-bunyi dengan huruf-huruf sewaktu mereka mengeja kata-kata.

Pada kegiatan akhir, peserta diajak untuk mengemukakan tentang pentingnya memperkenalkan kesadaran fonologis pada siswa dan menyusun rancangan pembelajaran membaca permulaan dengan berbasis kepada kesadaran fonologis.

\section{Hasil diskusi}

Pada saat diskusi dalam unit kegiatan ini diperoleh beberapa hal mengenai kesadaran fonologis yang dilakukan guru (peserta) selama ini di dalam kelas :

1. Mengenal bunyi huruf dilakukan dengan cara bernyanyi nama-nama huruf, dan menggunakan gambar, serta siswa mengikuti guru dalam pengucapan bunyi huruf

2. Mengenal suku kata dilakukan dengan cara menulis di papan tulis sebuah kata, lalu di bagi menjadi beberapa bagian suku kata, kemudian menghitung suku kata dalam kata

3. Mengenal kata dalam kalimat dilakukan dengan mengeja kata secara klasikal, mengunakan gambar-gambar (kartu kata) dan juga menggunakan buku paket yang digunakan siswa.

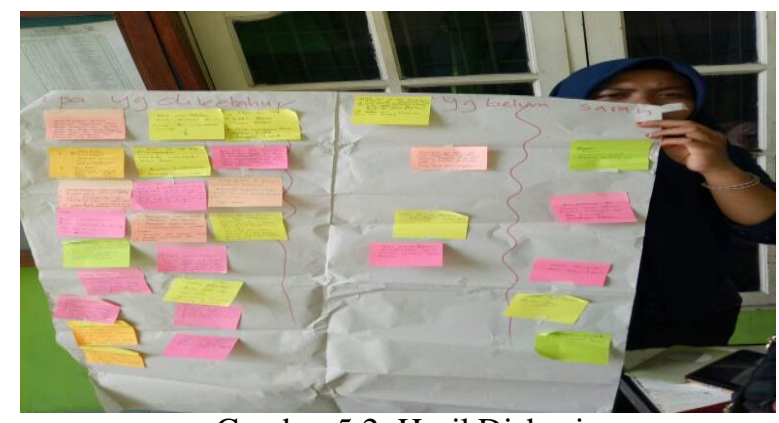

Gambar 5.2. Hasil Diskusi 


\section{Hasil Kegiatan dan Pembahasan}

Kesadaran fonologis ialah kemampuan untuk mendengar, mengidentifikasi, dan memanipulasi bunyi-bunyi bahasa. Ini merupakan keterampilan lisan dan merupakan kemampu an siswa untuk mendengar dan sadar akan bunyi-bunyi, menggunakan bunyi-bunyi tersebut untuk mengucapkan kata-kata, dan menggunakan bunyibunyi tersebut untuk membuat kata-kata baru.

Salah satu hal yang harus dirancang oleh guru agar anak memiliki kesadaran fonologis adalah suasana belajar. Suasana belajar dapat diciptakan melalui kegiatan permainan bahasa dalam pembelajaran membaca. Hal itu sesuai dengan karakteristik anak yang masih senang bermain. Permainan memiliki peran penting dalam perkembangan kognitif dan sosial anak.

Berikut beberapa hal yang dapat dikemukan mengapa kesdaran fonologi penting bagi ketrampilan membaca dan menulis siswa.

1) Terdapat perbedaan mendasar antara pembaca yang baik dan yang lemah terletak pada kemampuan pemrosesan fonologi pembaca yang baik.

2) Kesadaran fonologis diperlukan untuk menghubungkan bunyi-bunyi pada huruf-huruf. Ini adalah salah satu dari dua blok bangunan membaca, bersama dengan prinsip abjad/alfabet.

3) Siswa yang tidak dapat mendengar dan bekerja dengan fonem dari kata-kata yang diucapkan akan mendapat kesulitan belajar bagaimana berhubungan fonem-fonem ini ketika mereka melihatnya dalam kata-kata tertulis.

4) Mendorong pemahaman bacaan bagi siswa, tidak diragukan lagi karena hal ini membantu anak-anak membaca dan mengenali kata-kata secara efektif.

\section{Membacakan Cerita (Read Aloud)}

Kegiatan awal pada saat membacakan cerita, salah seorang fasilitator memodelkan membacakan cerita (read loud) berperan sebagai guru, sedangkan peserta (guru) berperan sebagai siswa kelas rendah (kelas 3). Sebelumnya telah disiapkan skenario dan buku yang diperlukan. Guru membaca sebuah buku cerita bergambar di depan kelas dan siswa memperhatikan. Guru mengajak siswa untuk menjawab pertanyaan guru, memprediksi cerita berdasarkan gambar, tokoh, alur cerita, dan hal-hal yang dianggap penting per halaman. Guru juga membaca dengan penuh ekspresi, perlahan dan jelas.

Setelah pemodelan selesai peserta diminta untuk mendiskusikan beberapa hal seperti, langkah-langkah membacakan cerita, strategi yang perlu dilakukan dan bahan yang diperlukan. Hasil diskusi dipresentasikan di depan kelas, dan ditanggapi oleh kelompok lain jika ada hal yang berbeda dan perlu didiskusikan sehingga ada kesamaan dalam hal membaca cerita ini.

Kegiatan inti pada unit ini yaitu setiap kelompok diberikan tugas untuk menentukan salah seorang anggota kelompok unutk ditunjuk sebagai model (guru) untuk mempraktekkan ketrampilan membaca cerita sesuai dengan langkah-langkah dan strategi yang telah didiskusikan sebelumnya dikelompok lain, duta masing-masing kelompok menjadi model dikelompok lain, anggota kelompok yang didatangi ditugasi untuk memberikan masukan terhadap guru (model).

Kegiatan akhir pada unit ini ditutup dengan menyampaikan hal-hal penting dalam membaca cerita serta strategi-strategi yang dilakukan, serta peserta diharpkan dapat mengembangkannya di dalam pembelajaran yang sesungguhnya.

\section{Hasil diskusi}

Pada saat diskusi dalam unit kegiatan ini diperoleh beberapa hal mengenai membaca cerita (read aloud) yang dilakukan guru (peserta) selama ini di dalam kelas :

1. Persiapan ketika membaca cerita tidak dituliskan dalam sebuah skenario

2. Guru membaca buku cerita di depan kelas dengan cara klasikal dan biasanya kurang berekspresi terhadap bacaan yang dibaca seperti intonasi yang datar, mimik wajah yang biasa saja dan seluruh siswa mengikuti apa yang dibaca guru

3. Guru juga menunjuk siswa untuk membaca cerita secara bergantian

4. Guru hanya menggunakan buku paket yang tersedia di sekolah saja

5. Guru kurang menggali informasi dari bacaan yang dibaca

6. Strategi yang digunakan dalam membaca cerita juga kurang variatif.

\section{Hasil Kegiatan dan Pembahasan}

Berikut ini langkah-langkah yang perlu diperhatikan dalam melakukan kegiatan membaca cerita (read aloud):

\section{Persiapan}

1. Memilih buku yang sesuai. Memilih buku dapat menggunakan pertimbangan berikut.

a. Pilih buku (dengan atau tanpa gambar) sesuaitema dan dapatmenjadi fokus perhatian siswa

b. Isi cerita disesuaikan dengan kebutuhan sebagian besar siswa (sesuai dengan usia, budaya, minat, alur jelas, mudah diingat, dst)

2. Menentukan tujuan membaca (apa yang ingin dikenalkan/dipahamkan kepada siswa dari kegiatan membaca)

3. Menuliskan skenario/alur kegiatan (kegiatan awal, inti, penutup)

Misal: 
- Halaman berapa dan bagian mana akan berhenti dan dipilih untuk menjadi fokus pemodelan (membahasnya/memberi pertanyaan, meminta siswa membuat prediksi, membuat koneksi/ dihubungkan dengan pengalaman pribadi siswa dan atau buku yang pernah dibaca).

\section{Kegiatan Awal Membaca}

1. Mengajak siswa mengenal buku, membahas penulis, judul, latar, karakter/tokoh, latar belakang (termasuk minta siswa membuat prediksi isi dan tokoh, latar, isi cerita, Berdasarkan judul buku minta siswa menyampaikan pengalaman yang mirip dengan judul)

2. Mengaktifkan/menggali pengetahuan utama dan pengetahuan umum siswa

3. Mengulas gambar (jika ada ilustrasi dan meningkatkan pemahaman dan ketertarikan awal siswa atas cerita pada buku atau genre buku)

4. Menyampaikan rangkuman singkat tentang cerita.

a. Membangun makna dengan menyampaikan isi singkat buku (mengajukan pertanyaan awal untuk membangun pemahaman awal siswa)

b. Melakukan perbandingan dengan pengalaman siswa (membandingkan bacaan/cerita dengan pengalaman dan atau bacaan yang pernah dialami dan atau dibaca siswa)

c. Memprediksi (meminta siswa memprediksi isi cerita)

d. Membandingkan dan mengontraskan ide dalam kelompok (membandingkan dengan cerita/buku yang pernah dibaca dan berbagi dengan teman)

\section{Selama Membaca}

1. Memberikan contoh membaca yang baik dan benar dalam pelafalan, jeda, gesture/gerak tubuh, ekspresi, dan juga intonasi.

2. Melakukan interaksi : Menghentikan membacakan cerita (jangan terlalu sering) untuk:

a. meminta siswa membuat prediksi kelanjutan cerita (setelah dibaca 1 halaman, pendapat siswa akan kegiatan yang akan dilakukan tokoh cerita berikutnya)

b. menghubungkan teks dan atau tema yang dibahas dengan pengalaman siswa atas apa yang sudah mereka baca dan atau alami sebelumnya

c. memberikan pertanyaan tentang makna teks yang dibaca (pemahaman), kosakata baru dan atau sulit, dan tata Bahasa. $\rightarrow$ pertanyaan selama membaca jangan terlalu banyak, agar momen tidak hilang, seperlunya saja untuk membantu pemahaman cerita.

d. Membantu siswa memperhatikan aspek informasi dan penjelasan atas teks (guru dapat menjelaskan berbagai keterampilan membaca selama proses membaca, misal, kosakata baru, tata Bahasa, dll) e. Memberikan kesempatan siswa untuk bertanya tentang kata yang tidak dipahami, isi cerita, dan juga pendapat siswa, dll

f. Menerapkan Think Aloud: Guru memodelkan cara merancang pertanyaan tentang kejadian dan tokoh di dalam cerita dan mendorong siswa untuk membuat pertanyaan

g. Kata sulit yang tidak dipahami siswa tidak selalu harusdijelaskan secara tuntas, dapat dibawa saat Membaca Terbimbing

h. Memberikan pertanyaan eksplisit/Tekstual (yang jawabannya ada di dalam teks) dan pertanyaan inferensial (jawaban tidak secara langsung tertulis di dalam cerita) $\rightarrow$ kegiatan ini dimaksudkan untuk membantu siswa memahami isi cerita)

3. Memunculkan adanya respons dan diskusi siswa (guru dapat menghentikan kegiatan membaca, meminta siswa menyampaikan pemahaman atas bacaan yang didengar,mengklarifikasi dan meluruskan miskonsepsi, dan meminta siswa melakukan prediksi lanjutan atas kelanjutan cerita)

\section{Setelah Membaca}

Kegiatan Read Aloud tidak selalu harus diikuti kegiatan lanjutan, tetapi kegiatan lanjutan juga dapat diberikan. Kegiatan lanjutan dimaksudkan agar siswa dapat melanjutkan belajarnya dan memahami bacaan. Kegiatan yang dapat dipilih dan atau dikembangkan, misalnya;

1. Memberikan pertanyaan diskusi (dimana lokasi terjadinya cerita?, siapa tokoh utamanya? Apa masalah yang terjadi? Bagaimana mereka mendapatkan solusi? Apa yang ingin disampaikan penulis kepada kita/pembaca?)

2. Berdiskusi tentang isi cerita (untuk meningkatkan pemahaman tentang isi cerita, siswa diminta berdiskusi isi cerita dengan siswa lain)

3. Berdiskusi respons mereka atas cerita dan pengalaman mereka, teks cerita yang lain, dan pengetahuan mereka atas dunia.

4. Menceritakan kembali isi cerita secara lisan, tulisan dan atau dalam bentuk gambar.

5. Siswa juga dapat diminta menceritakan kembali isi cerita dalam bentuk peta cerita (misal: dengan menanyakan, apa yang terjadi di awal, tengah dan akhir cerita?)

6. Mengajak siswa menjawab pertanyaan imajinasi denganmembayangkan seandainya mereka adalah tokohnya (tutup mata kalian, bayangkan kalian adalah tokohnya dan mengalami semuanya, apa yang akan kalian lakukan?)

7. Meminta siswa merefleksikan pemahaman mereka atas teks

8. Meminta siswa melakukan Think Aloud (menyampaikan hasil pemikiran atas cerita yang didengar/disimak secara lisan dan atau tulis)

9. Guru melatih siswa meningkatkan kemampuan metakognisi (mengajak siswa memikirkan apa yang dipikirkan teman atau orang lain atas cerita yang dibacakan) 
10. Guru juga dapat memberikan pertanyaan yang menyenangkan (misal: siapa tokoh favorit kalian dan mengapa? Jika kalian menulis ulang cerita tersebut dan menutup cerita, apa yang akan kalian ubah? Jika kalian dapat bertemu salah satu tokoh dalam cerita, siapa yang akan kalian temui kemudian apa yang akan kalian sampaikan ke dia?)

11. Siswa dapat diberikan tugas menyampaikan pemahaman mereka atas bacaan dengan Think Aloud (menyampaikan pendapat dan pemahaman atas cerita yang dibacakan secara lisan dan atau tulis) dan Writing Aloud (menyampaikan pemahaman dan gagasan siswa atas bacaan dalam bentuk tulis)

Selain mengetahui langkah juga diperlukan strategi yang digunakan untuk meningkatkan pemahaman siswa selama membacakan cerita (read aloud) sebagai berikut :

\section{a. Memprediksi}

Memprediksi ialah suatu strategi pemahaman membaca di mana siswa menggunakan petunjuk dari teks dan pengetahuan awal mereka untuk memprediksi apa yang akan terjadi di teks tersebut. Petunjuk-petunjukdaritekstermasukjudul teks,gambar-gambar,danfitur-

fiturpentingdalamtekssepertipotongantulisan(capti ons),kata-katayangdipertebal,danjudul.

\section{b. Membuat Koneksi}

Ketika membuat koneksi, siswa menggunakan pengetahuan personal mereka, dari teks-teks lainnyadan/atau pengalaman-pengalaman kehidupan untuk membantu mereka memahami arti dari teks.

c. Meringkas

Dalam hal meringkas, siswa menggunakan katakata mereka sendiri untuk mengidentifikasi ideidepenting, fakta-fakta, dan informasi dari bacaan. Dalam mengembangkan keterampilanketerampilanbahasa lisan, guru dapat memberikan pertanyaan-pertanyaan (scaffolding) untuk membantu siswameringkas.

d. Membuat Kesimpulan

Ketika membuat kesimpulan, siswa menggunakan petunjuk-petunjuk dari bacaan atau pengetahuanpersonal untuk membuat kesimpulan. Kesimpulan dapat diambil dari informasi tidak langsungatau langsung dinyatakan dalam teks. Siswa dapat menjawab secara lisan untuk mengembangkanketerampilan-keterampilan

bahasa lisan mereka. Siswa dapat juga menjawab pertanyaan-pertanyaan kesimpulan dari pelajaran tersebut (misalnya, membahas nilai-nilai moral dari cerita tersebut).

e. Membacakan Ulang

Pada saat membacakan ulang buku, kegiatankegiatan dapat menjadi lebih interaktif. Siswa dapatmembangun pemahaman yang dalam mengenai isi: diskusi dapat lebih terfokus; dan siswa dapatmenghubungkan informasi dengan pengalaman-pengalaman mereka sendiri.
Membaca ulang dapat jugamembangun baik kemampuan mengingat informasi dan kemampuan untuk mengomunikasikan apayang telah dipelajari.Melalui kegiatan-kegiatan belajar seperti yang dibahas di atas (mis, buku besar), guru dapat memberikanpertanyaan pada siswa, berfokus baik pada keterampilan menyimak/mendengar maupun keterampilanberbicara.

\subsection{Penilaian Membaca (Running Record)}

Pada kegiatan awal peserta diberi penjelasan mengenai latar belakang, tujuan pembelajaran dan garis besar kegiatan. Peserta diajak untuk mengemukakan pendapatnya mengenai bagaimana kemampuan membaca siswa berdasarkan tayanan video yang diberikan. Hasil diskusi ditulis di kertas plano dan dipresentasikan di depan kelas untuk didiskusikan dengan hasil diskusi kelompok lain. Penilaian membaca siswa difokuskan pada beberapa hal di antaranya mengenai benar atau salah kata yang dibaca siswa dan banyaknya koreksi diri yang dilakukan siswa pada saat membaca kata-kata dalam suatu kalimat

Pada kegiatan inti, peserta berdiskusi secara berpasangan dengan teman kelompoknya mengenai unsur-unsur yang dinilai dan tanda-tanda pada lembar pengamatan penilain membaca. Dengan menggunakan lembar pengamatan yang diberikan, peserta diajak kembali untuk mengamati video mengenai penggunaan lembar pengamatan penilaian membaca seorang siswa dan cara memberikan penilaiannya. Salah seorang peserta ditunjuk untuk menyampaikan hasil analisisnya dan dilanjutkan dengan pemberian penguatan oleh fasilitator. Peserta diberi penjelasan mengenai hal-hal yang dianggap salah dan benar pada saat membaca sebuah kalimat, juga hal-hal yang dianggap sebagai koreksi diri.

Pada kegiatan akhir, peserta berdiskusi mengenai penting penilai membaca bagi seorang guru terhadap siswa-siswinya di dalam kelas. Penilaian membaca ini juga diharapkan dapat dilakukan siswa dengan level kelas yang berbeda sehingga guru dapat memperoleh data mengenai pengelompokkan/klasifikasi tingkatan (level) siswanya di dalam kelas, sehingga dapat dilakukan langkah-langkah yang dapat membantu siswa untuk lebih lancar dalam membaca. Karena ketrampilan membaca siswa memiliki dampak terhadap pemahaman siswa terhadap isi bacaan, dengan pemahaman yang baik akan meningkatkan kemampuan belajar dan berhubungan terhadap prestasi siswa dalam pembelajaran.

\section{Hasil diskusi}

Pada saat diskusi dalam unit kegiatan ini diperoleh beberapa hal mengenai penilaian membaca (running record) yang dilakukan guru (peserta) selama ini di dalam kelas : 
1. Penilaian membaca dilakukan dengan cara siswa disuruh membaca buku yang ditentukan guru, secara bergantian. Siswa yang lancar membaca diberikan bacaan yang lebih panjang dari pada siswa yang belum bisa membaca, sedangkan siswa yang tidak bisa membaca tidak diberi kesempatan untuk membaca

2. Siswa dikelompokkan ke dalam kelompok tidak bisa membaca jika masih mengeja dalam membaca, sedangkan yang tidak mengeja sudah dianggap lancar membaca, sehingga belum ada kriteria yang jelas mengenai tingkatan (level) membaca siswa di dalam kelas

3. Biasanya siswa yang belum atau tidak bisa membaca duduk berhadapan langsung dengan meja guru.

\section{Hasil Kegiatan dan Pembahasan}

Teknik penilaian yang sesuai dengan kebutuhan siswa sangat penting dikuasai oleh guru. Penilaian untuk mengukur pemahaman siswa sering dilakukan oleh guru. Namun teknik penilaian untuk mengukur banyaknya kata yang salah atau benar yang dibaca siswa belumlah familiar bagi guru.

Penilaian membaca salah satunya yaitu Running record adalah suatu kegiatan yang bertujuan untuk menilai sampai sejauh mana seorang siswa dapat membaca. Dengan menggunakan suatu instrumen, seorang guru dapat mengetahui jumlah kata yang dibaca dengan benar atau salah dan jumlah koreksi diri serta sikap membacanya.

Running record adalah suatu kegiatan yang bertujuan untuk menilai sampai sejauh mana seorang siswa dapat membaca. Dengan menggunakan suatu instrumen, seorang guru dapat mengetahui jumlah kata yang dibaca dengan benar atau salah dan jumlah koreksi diri serta sikap membacanya.

Ketika membaca seorang siswa dianggap salah jika mengganti kata, menghilangkan kata, menambah kata, diberi tahu seluruh kalimat yang dibaca sedangkan ketika siswa mengulang kata, mengulang kalimat/frase, melakukan koreksi diri, membutuhkan intervensi guru karena bingung atau tidak mau mencoba dan membutuhkan intervensi guru untuk membaca satu kata maka hal-hal ini dianggap tidak salah di dalam penilaian membaca. Selanjutnya memiliki pemahaman yang sama mengenai tanda yang diberikan pada lembar penilaian. Langkah berikutnya yaitu penilaian dengan cara menjumlahkan total kata dikurangi total kesalahan dibagi dengan total kesalah dikali $100 \%$ sehingga akan diperoleh tingkat akurasi dan level pembaca bagi seorang siswa termasuk ke dalam mandiri $(95 \%$ - 100\%), berkembang (90\% - 94\%) dan perlu bimbingan (kurang dari 90\%).

Hasil penilaian dapat dimanfaatkan sebagai dasar penempatan seorang siswa berdasarkan kemampuan membacanya. Buku-buku bacaan dan kegiatan membaca siswa kemudian disesuaikan dengan kebutuhannya.

\subsection{Ketrampilan Menulis}

Pada kegiatan awal peserta diberi penjelasan mengenai latar belakang, tujuan pembelajaran dan garis besar kegiatan. Peserta diminta untuk berdiskusi tentang strategi yang digunakan guru dalam mengajarkan ketrampilan menulis dan bagaimana pengalaman ketika menerapkan strategi tersebut. Kemudian dipresentasikan di depan kelas.

Pada kegaiatan inti, peserta diajak berdiskusi mengenai langkah-langkah strategi pemodelan menulis dan strategi menulis bersama melalui pengamatan video kegiatan yang ditayangkan oleh fasilitator. Hasil diskusi dipresentasikan di depan kelas oleh sala satu kelompok, sedangkan kelompok lain memberikan tanggapan, kritikan dan masukan. Selanjutnya peserta diminta menunjukkan salah seorang di dalam kelompok sebagai guru dan lainnya sebagai siswa untuk melakukan simulasi kegiatan strategi pemodelan menulis dan strategi menulis bersama di dalam kelompoknya masing-masing. Kemudian fasilitator memodelkan strategi menulis mandiri, Fasilitator berperan sebagai guru dan para peserta berperan sebagai siswa dengan membuat mini book terlebih dahulu. Dengan menggunakan mini book peserta dalam menuliskan sesuatu sesuai dengan kegemaran masing-masing menggunakan pensil berwarna, dilengkapi dengan halaman depan (cover) dan isi buku dilengkapi dengan gambar warna-warni. Hasil mini book ini dipajang di depan kelas sebagai produk dari strategi menulis mandiri.

Pada kegiatan akhir peserta diminta untuk mengemukan pendapatnya mengenai pentingnya langkah-langkah dan strategi dalam ketrampilan menulis siswa di kelas. Selanjutnya peserta juga diminta untuk dapat mempraktikkan tiga strategi menulis di kelasnya masing-masing.

\section{Hasil diskusi}

Pada saat diskusi dalam unit kegiatan ini diperoleh beberapa hal mengenai ketrampilan menulis yang dilakukan guru (peserta) selama ini di dalam kelas :

1. Strategi pemodelan menulis baisanya dilakukan guru dengan mencontohnya tulisan di papan tulis dan menulis huruf di udara.

2. Strategi menulis bersama biasanya dilakukan guru dengan cara menggunakan contoh yang ada di buku halus kasar siswa.

3. Strategi menulis mandiri biasanya dilakukan guru dengan cara, siswa disuruh menulis pengalaman ketika liburan atau mengenai kegemaran siswa.

\section{Hasil kegiatan dan Pembahasan}

Kesuksesan siswa dalam mencapai keterampilan menulis, erat kaitannya dengan dukungan guru dalam memilih dan menerapkan strategi menulis yang tepat, sesuai dengan kebutuhan dan kemampuan siswa. Ada 
beberapa strategi yang dapat diterapkan guru dalam pembelajaran menulis, yaitu strategi pemodelan menulis, menulis bersama, menulis interaktif, menulis terbimbing, dan menulis mandiri.

\section{Strategi Pemodelan Menulis}

Dalam kegiatan pemodelan menulis, guru dapat mendemonstrasikan banyak hal. Salah satu contoh langkah-langkah pemodelan yang dapat dilakukan guru adalah sebagai berikut.

1. Guru menunjukkan gambar sebuah bola.

2. Guru membunyikan dengan nyaring kata "bola".

3. Guru menyebut nama huruf satu per satu, "b", "o", "l", "a". Setelah itu guru membunyikan nama huruf tersebut satu per satu /b/, /o/, /l/, /a/.

4. Guru mulai menuliskan perlahan huruf " $b$ " sambil tetap membunyikannya. Guru harus memastikan semua siswa dapat melihat dengan jelas gerakan tangan guru saat menulis huruf $b$. Hal yang sama dilakukan sampai dengan huruf terakhir.

5. Guru harus dapat memodelkan menulis huruf demi huruf dengan meminimalisir mengangkat tangan saat menulis. Membiasakan siswa menulis huruf dengan satu tarikan atau tarikan paling sedikit akan membuat siswa tidak lelah dalam menulis.

6. Siswa mencontoh model yang ditulis guru.

\section{Strategi Menulis Bersama}

Dalam menerapkan strategi menulis bersama ini, guru memodelkan bagaimana memunculkan ide tulisan, memilih kosakata, dan menggambarkan bahasa ke dalam sebuah tulisan. Guru memandu aktivitas menulis baik secara individu maupun kelompok. Pada kegiatan itulah, guru bekerja dengan siswa untuk mengorganisasikan ide dan menyiapkan outline.

Berikut ini langkah-langkah yang dapat dilakukan dalam menerapkan strategi menulis bersama.

1. Guru menyiapkan alat/bahan yang dibutuhkan, seperti
a. buku bergaris,
b. pensil,
c. buku tulis

2. Guru memilih satu benda untuk dijadikan sebagai judul cerita.

3. Guru menuliskan judul cerita di papan tulis.

4. Guru memulai kegiatan menulis bersama dengan menulis sebuah kalimat yang berkaitan dengan judul.

5. Siswa melanjutkan kalimat guru dengan menambahkan kalimat. Satu siswa mendapatkan kesempatan melanjutkan cerita dengan menulis satu kalimat yang berkaitan dengan kalimatkalimat sebelumnya. Begitu seterusnya hingga cerita selesai dibuat.

6. Guru memberikan masukan terhadap tanda baca, ejaan, dan lainnya.
7. Setelah menulis cerita selesai, kegiatan berikutnya adalah menyunting cerita. Pada proses penyuntingan, guru meminta salah seorang siswa membaca hasil karya, kemudian melakukan penyuntingan secara bersama-sama.

8. Guru dan siswa membaca cerita bersama-sama.

9. Untuk latihan berikutnya, guru dapat meminta setiap kelompok membuat cerita bersama dengan cara yang telah dicontohkan. Sebagai sumber inspirasi, guru dapat mengarahkan mereka untuk mengambil salah satu benda yang ada di meja mereka, kemudian membuat cerita tentang benda tersebut.

\section{Strategi Menulis Mandiri}

Setelah siswa mendapatkan pengetahuan dan pengalaman melalui kegiatan pemodelan menulis dan menulis bersama, guru dapat mengarahkan mereka untuk menulis mandiri. Pada kegiatan menulis mandiri, guru dapat menggunakan media mini book. Pada kegiatan ini, siswa dapat membuat cerita sekaligus menggambarkan cerita tersebut dengan gambar yang dibuatnya sendiri. Menulis mandiri dengan menggunakan media mini book akan membuat siswa semakin asyik menulis cerita sambil menggambar.

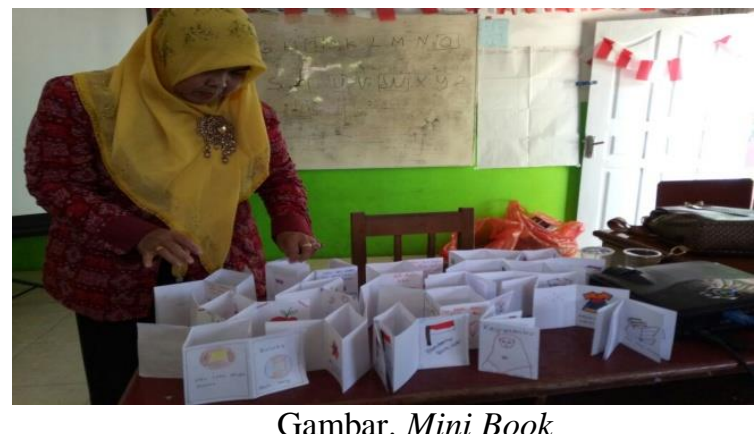

Berikut ini langkah-langkah dalam menerapkan strategi menulis mandiri.

1. Guru menunjukkan contoh mini book, memperkenalkannya kepada siswa, dan membacakan ceritanya.

2. Guru membagikan kertas hvs kepada setiap siswa, kemudian membimbing mereka untuk melipat kertas menjadi media mini book.

3. Siswa menentukan cerita yang akan dibuat. Pada langkah ini, guru dapat membantu siswa mencari ide cerita. Ide cerita dapat diambil dari hal-hal yang dekat dengan siswa agar siswa mudah membuat ceritanya. Misalnya, untuk kelas 1, ide cerita dapat diambil dari bendabenda kesayangan mereka. Untuk kelas lebih tinggi, guru dapat meminta mereka mengingat pengalaman mereka kemarin. Kisah pengalaman tersebut dapat dijadikan sebagai cerita mereka.

4. Siswa mulai membuat draft cerita.

5. Siswa menulis cerita di mini book berdasarkan draft yang sudah dibuat. Satu halaman dapat terdiri dari satu kata atau satu kalimat sederhana. Pada kelas lebih tingga, siswa dapat 
membuat beberapa kalimat di setiap halaman (4 halaman mini book).

6. Siswa melengkapi mini book dengan gambar.

7. Setelah mini book selesai, siswa membacakan ceritanya di depan kelas.

8. Pada tahap berikutnya, guru dapat memberikan keleluasaan kepada siswa untuk berkreasi membuat cerita mini book dan memberi beragam gambar/hiasan menarik yang berkaitan dengan cerita.

\section{DAFTAR PUSTAKA}

Armbruster, B. B., Lehr, F., \& Osborn, J. (2001). Putreadingfirst: The research Building Blocks for teaching children to read. Washington, D.C.: National Institutefor Literacy.

Beck, I. (2004). Cunningham, A., \&Stanovich, K. (1998). What reading does for the mind. American Educator, 22 (1 \& 2), 8-15.

Hahn, M.L. (2002) Reconsideringread-aloud. Maine: StenhousePublishers.

Juel, C. Griffith, P. L., \& Gough, P. B. (1986). Acquisition of literacy: A longitudinal study of children in first and second grade. Journal of Educational Psychology, 78, 243-255.

Musfiroh, Tadkiroatun (2008). Memilih, Menyusun, dan Menyajikan Cerita untuk Anak Usia Dini. Yogyakarta: Tiara Wacana.

Neuman, S.B., Bredekamp, S., \&Copple, C. (2000). Learningtoreadandwrite:

Developmentallyappropriatepractice. Washington, DC: NAEYC.

Sorenson, S. (2010) Webster's New World Student Writing Handbook. Fifth Edition. Canada: Wiley Publishing.

Selengkapnya

http://www.kompasiana.com/ronaldhutasuhut/ laporan-peringkat-hdi-indonesia-terbaru2016_58d20bc4519773ed0964b01c (diunduh tanggal 11 Mei 2017)

http://www.republika.co.id/berita/koran/didaktika/14/ 12/15/ngm3g840-literasi-indonesia-sangatrendah (diunduh tanggal 11 mei 2017). 